\title{
Scalp and skull bone metastasis in cervical carcinoma-a rare entity
}

\author{
José Fernando Robles Díaz, Adela Heredia Zelaya and Alicia Milagros Avalos Rosas
}

National Institute of Neoplastic Diseases, Lima 34, Av. Angamos Este 2520 Surquillo, Lima, Peru

\begin{abstract}
Cervical cancer is the second most common cancer in women worldwide and the first in Peru; however, metastasis to the cranial scalp is extremely rare. We present the case of a 41-year-old woman diagnosed with cervical cancer IIIB, who received treatment based on concurrent pelvic radiotherapy with chemotherapy followed by brachytherapy at the primary level with complete response, developing, at 18 months, a metastatic lesion at the scalp level without evidence of recurrence in the cervix. With the rapid growth of the metastatic lesion leading to the destruction of the cranial cap, the meninges can be observed directly, without presenting to the neurological clinic.
\end{abstract}

Keywords: Uterine cervical neoplasms, neoplasm metastasis, scalp and skull

\section{Introduction}

Cervical cancer is the second most common malignancy in women worldwide and the most common type of cancer in women in many developing countries, mainly in Latin America [1-3]. It occurs in the reproductive period of life, with increasing incidence from 30 to 34 years of age, and a peak at 55-65 years [4].

With cervical cancer being the most common malignancy with a frequency of $24.1 \%$ among women in Peru [5], scalp metastasis is extremely rare.

The following is an unusual case of single scalp metastasis from clinical stage IIIB cervical carcinoma treated with radical external radiotherapy.

\section{Case report}

In March 2015, a 41-year-old woman presented with gynecorrhagia associated with pelvic pain of 3 months duration. On physical examination, a $5-\mathrm{cm}$ cervical tumour was found with infiltration of the upper third of the vagina, both parameters predominantly left to the pelvic bone, with clinical stage IIIB cervical cancer being diagnosed. Cervical biopsy reported moderately differentiated non-keratinising infiltrating epidermoid carcinoma. Chest $\mathrm{X}$-ray imaging and multi-slice spiral pelvic abdominal tomography (MST)
Correspondence to: José Fernando Robles Díaz Email: bayern014@hotmail.com

ecancer 2019, 13:969

https://doi.org/10.3332/ecancer.2019.969

Published: $17 / 10 / 2019$

Received: 28/05/2019

Publication costs for this article were supported by ecancer (UK Charity number 1176307).

Copyright: (c) the authors; licensee ecancermedicalscience. This is an Open Access article distributed under the terms of the Creative Commons Attribution License (http:// creativecommons.org/licenses/by/3.0), which permits unrestricted use, distribution, and reproduction in any medium, provided the original work is properly cited. 
showed no signs of metastasis, except mild to moderate left hydronephrosis. She received external radiotherapy at a dose of 5,000 cGy in 25 sessions in pelvic fields in anteroposterior and posterior-anterior technique concurrent with carboplatin, followed by two sessions of 600 cGy at parametrial level with teletherapy. At 5 weeks, due to good parametrial response, she received two applications of high-rate brachytherapy of 800 cGy, ending in August 2015. For 18 months, she found herself free of disease.

In March 2017, she presented an increase in volume at the left parietal level of the scalp with an approximate size of $4 \mathrm{~cm}$ fixed to the bone. Brain MST was performed, indicating the presence of a solid lesion at the left parietal level, which replaced the $5 \mathrm{~cm} \times 7 \mathrm{~cm}$ bone marrow and compromised the dura mater, subcutaneous cellular tissue and adjacent skin (Figure 1). Biopsy of the lesion reported moderately differentiated non-keratinising infiltrating epidermoid carcinoma. The patient lost her sight, and in June 2017, magnetic resonance imaging (MRI) was performed (Figure 2), showing bilateral parietal lesion with predominantly ulcerated, necrotic left that infiltrated the pachymeninges and a new lesion at the right frontal level. She was evaluated by the Department of Head and Neck Surgery, being catalogued as non-surgical. She was evaluated in the Radiotherapy department, where an ulcerated parietal level lesion with raised edges on scalp with extensive involvement was found, and with the diffuse of soft tissues with destruction of the skull of approximately $9 \mathrm{~cm}$ exposing the meninges at the parietal level and an elevated lesion of $3 \mathrm{~cm}$ at the right frontal level of hard, non-ulcerated consistency was also found (Figures 3 and 4 ).

In a multidisciplinary meeting, it was decided to treat with radiotherapy in opposite lateral fields, covering the two lesions of the cranial cap at a dose of 5,100 cGy in 17 sessions at $300 \mathrm{cGy}$ per fraction (Figure 5). Eighteen months later, she is currently under follow-up, resulting in daily healing and complete pain relief (Figure 6).

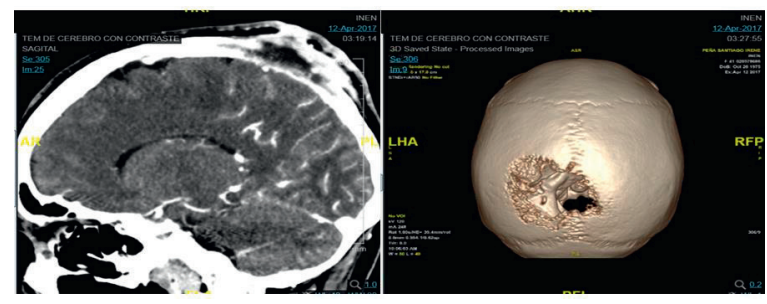

Figure 1. Brain MST (12.04.17): In the left parietal region, there is a solid lesion that replaces the bone marrow, measuring approximately $5.2 \mathrm{~cm} \times 2 \mathrm{~cm}$, infiltrating the dura mater, subcutaneous cellular tissue and adjacent skin.

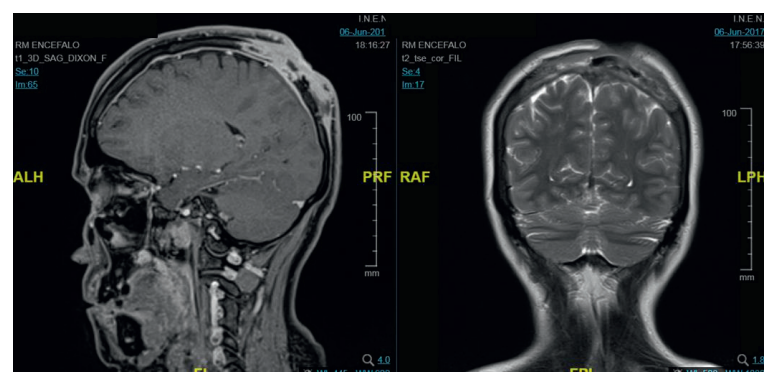

Figure 2. Brain MRI (06.06.17): Neoformative tissue, which infiltrates the bone marrow of the cranial calotte, in the right frontal bone, left occipital with bilateral parietal bone to left predominance, the latter infiltrates the adjacent soft parts, necrotic and ulcerated in the adjacent subcutaneous plane associated with osteolysis of the calotte, infiltrates the adjacent pachymeninges and the posterior aspect of the interhemispheric furrow, without infiltration of the parenchyma. 


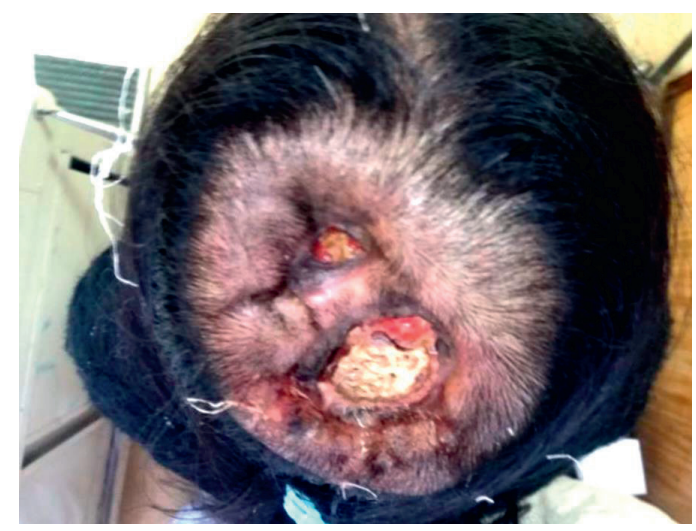

Figure 3. Photo of 04.07.17, with evidence of injury at the parietal level with the destruction of the cranial shell exposing the meninges.

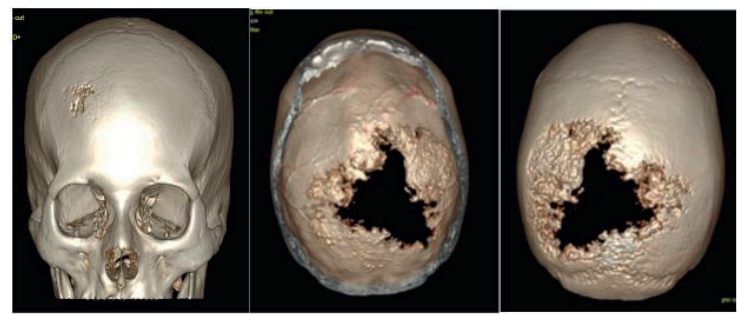

Figure 4. Brain MST (05.07.17): Expansive lytic lesion in the left parietal bone measuring approximately $8.37 \mathrm{~cm} \times 3 \mathrm{~cm}$, infiltrating the meninges. Another lesion of the same characteristics which measures $2.3 \mathrm{~cm} \times 0.95 \mathrm{~cm}$ at the level of the right frontal bone.

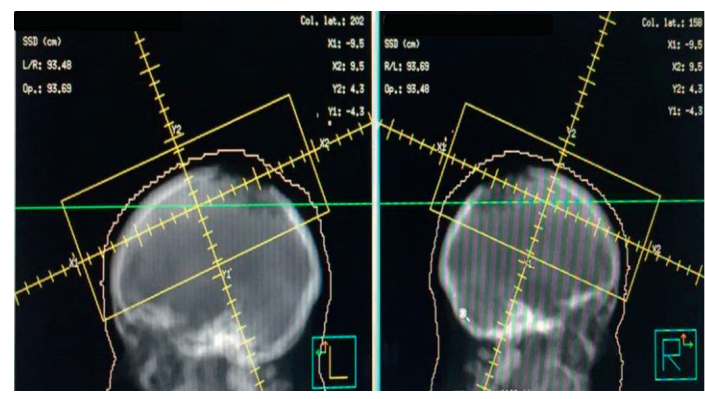

Figure 5. Opposite lateral treatment field covering the two lesions at 51Gy in 17 sessions with photons.

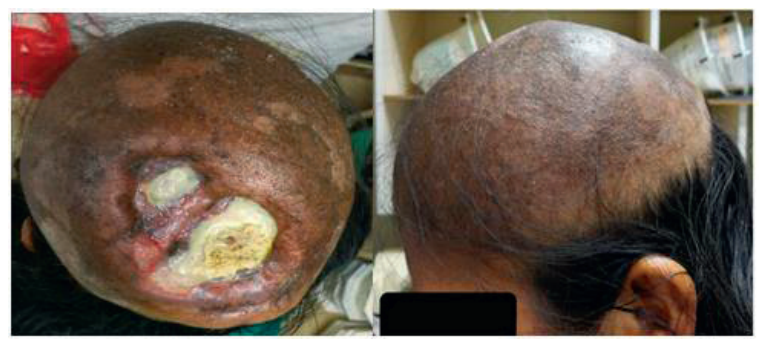

Figure 6. Photo of 09.08.17, 10 days after radiotherapy treatment. Borders of ulcers in reepithelialisation, no bleeding. 


\section{Discussion}

The spread of cervical cancer usually occurs by contiguous extension, extending from the cervix to para-cervical tissues, vaginal and parametrial tissues, to the bladder and/or rectum in advanced stages. On the other hand, it can spread through the lymphatic system spreading to the primary pelvic nodes, continuing with the common and para-aortic iliac [6]. However, the hematogenous spread is infrequent, occurring in advanced stages of the disease, especially in the lung, liver, bones and non-regional lymph nodes [1-3].

There are isolated reports of distant metastases in unusual sites such as orbit, brain, breast, heart, thyroid, kidney, spleen, intestine, muscle and scalp [7, 8], the skin of the abdomen and lower limbs are usually affected, possibly because of proximity to the pelvic region, skin involvement being considered infrequent $[1,2,8]$.

Scalp metastasis is very rare, and, so far, has been previously reported in only eight studies, and suggests not being related to the initial stage of presentation as it is detected in patients treated in early stages as well as advanced (Table 1) [1, 2, 3, 7, 9-12]. The spread that is probably explained through the hematogenous pathway, as tumour plungers that reach the branches of the external carotid artery, with the consequent local implantation [2]. Of the seven cases that were managed with radiotherapy alone, Agarwal et al [2] reported in 2002 a case of metastatic carcinoma of cervical cancer IIIB, receiving radiotherapy of 2,000 cGy in five sessions at the scalp level with complete relief of bone pain. Also, Takagi et al [3] reported in 2010 a scalp metastasis with compromise of both skull tables of cervix cancer IIB, treated with radiotherapy of 4,500 cGy in 15 sessions and Vitorino et al [7] in 2013, handled a metastatic lesion with invasion of skull and brain by surgical resection aimed at the treatment of established intracranial hypertension and neoplastic cytoreduction, with the objective of promoting a better response to adjuvant radiotherapy.

Table 1. Cases of scalp metastases from cervical cancer.

\begin{tabular}{|c|c|c|c|c|c|c|c|c|c|c|}
\hline $\mathrm{N}$ & Origin & Age & EC & Histological type & GD & Primary treatment & PLE & $\begin{array}{c}\text { Treatment of } \\
\text { metastasis }\end{array}$ & $\begin{array}{c}\text { Metastatic lesion } \\
\text { control }\end{array}$ & Ref \\
\hline 1 & Japan & 59 a & IIIB & Squamous cell carcinoma & III & RT & $4 \mathrm{~m}$ & None & Dies in 3 months & [9] \\
\hline 2 & India & $45 a$ & IB & Squamous cell carcinoma & I & - & - & RT & - & [10] \\
\hline 3 & India & $45 a$ & IIB & Squamous cell carcinoma & - & $\begin{array}{l}\mathrm{RT}(50 \mathrm{~Gy} / 25 \mathrm{Fx} \\
+\mathrm{RIC})\end{array}$ & $8 \mathrm{~m}$ & $\begin{array}{l}\text { RT } \\
(4,500 c G y / 15 F x)\end{array}$ & 4 months & [1] \\
\hline 4 & India & $60 a$ & IIIB & Squamous cell carcinoma & II & $\begin{array}{l}\mathrm{RT}(45 \mathrm{~Gy} / 20 \mathrm{Fx} \\
+\mathrm{RIC})\end{array}$ & $2 \mathrm{~m}$ & $\begin{array}{l}\text { RT } \\
(2,000 c G y / 5 F x)\end{array}$ & - & {$[2]$} \\
\hline 5 & Japan & $45 a$ & IB1 & Squamous cell carcinoma & III & $\mathrm{RRHH}$ & $7 a$ & None & Dies in 3 months & [11] \\
\hline 6 & India & $53 a$ & IIA & Adenocarcinoma & II & $\begin{array}{l}\mathrm{HR}+\mathrm{RT}(28 \\
\mathrm{Gy} / 14 \mathrm{Fx})\end{array}$ & $4 \mathrm{~m}$ & $\begin{array}{l}\mathrm{RT}(3,000 \\
\mathrm{cGy} / 10 \mathrm{Fx})\end{array}$ & - & [12] \\
\hline 7 & Japan & $48 \mathrm{a}$ & IIB & $\begin{array}{l}\text { Squamous cell carcinoma } \\
\text { small cell }\end{array}$ & - & $\begin{array}{l}\mathrm{HR}+\mathrm{RT} \\
(45 \mathrm{~Gy} / 20 \mathrm{Fx}) / \mathrm{QT}\end{array}$ & $2 \mathrm{~m}$ & $\begin{array}{l}\mathrm{RT}(4,500 \\
\mathrm{cGy} / 15 \mathrm{Fx})\end{array}$ & - & [3] \\
\hline 8 & Brazil & $55 \mathrm{a}$ & IIIB & Squamous cell carcinoma & - & - & - & Resection + RT & - & [4] \\
\hline 9 & Peru & $41 \mathrm{a}$ & IIIB & Squamous cell carcinoma & II & $\begin{array}{l}\text { RT }(50 G y / 25 F x+ \\
\text { BAT)/QT }\end{array}$ & $18 \mathrm{~m}$ & $\begin{array}{l}\mathrm{RT}(5,100 \mathrm{cGy} / 17 \\
\mathrm{Fx})\end{array}$ & 18 weeks & - \\
\hline
\end{tabular}

Legend: EC, clinical Stage; GD, degree of differentiation; PLE, disease-free period without metastasis; Ref, literature reference; RT, radiotherapy; HR, radical hysterectomy; RIC, intracavitary radiotherapy; BAT, high-dose rate brachytherapy; QT, concurrent chemotherapy. 


\section{Conclusion}

The presence of a tumour lesion at the head level in a patient with cervical cancer should be considered clinically whether it is a second primary or a metastatic tumour. Diagnostic methods should include imaging studies such as MST and MRI of the brain, which provide useful clues, making biopsy essential for this. It is important to distinguish a primary scalp tumour from a metastatic deposit, since not only does the management and prognosis of the patient change, because it is an exceptionally rare case, but the treatment is individualised, with the aim of controlling symptoms and improving the quality of life.

\section{Funding}

This study was funded by the Radiotherapy Department of the National Institute of Neoplastic Diseases.

\section{Conflicts of interest}

There are no potential conflicts of interest involved in this research.

\section{Acknowledgments}

The authors would like to thank the Plan Esperanza, funded by the Peruvian government.

\section{References}

1. Maheshwari G, Baboo H, and Ashwathkumar R, et al (2001) Scalp metastasis from squamous cell carcinoma of the cervix Int J Gynecol Cancer 11 244-246 https://doi.org/10.1046/j.1525-1438.2001.00074.x PMID: 11437934

2. Agarwal U, Dahiya P, and Chauhan A, et al (2002) Scalp metastasis in carcinoma of the uterine cervix - a rare entity Gynecol Oncol 87 310-312 https://doi.org/10.1006/gyno.2002.6829 PMID: 12468331

3. Takagi H, Miura S, and Matsunami K, et al (2010) Cervical cancer metastasis to the scalp: case report and literature review Eur J Gynaec Oncol 31 217-218

4. Sankaranarayanan R and Ferlay J (2006) Worldwide burden of gynecological cancer: the size of the problem Best Pract Res Clin Obstet Gynaecol 20 207-225 https://doi.org/10.1016/j.bpobgyn.2005.10.007

5. Dirección general de epidemiología. Análisis de la situación del cáncer en el Perú 2013 [http://www.dge.gob.pe/portal/ docs/asis cancer.pdf]

6. Lobo RA, Gershenson DM, and Lentz GM, et al (2017) Comprehensive Gynecology 7th edn (Philadelphia: Elsevier)

7. Vitorino-Araujo JL, Veiga JC, and Barboza VR, et al (2013) Scalp, skull and brain metastasis of squamous cell carcinoma of the cervix - a rare entity Br J Neurosurg 27 519-520 https://doi.org/10.3109/02688697.2013.764971 PMID: 23410006

8. Bhandari V, Kausar M, and Naik A, et al (2016) Unusual metastasis from carcinoma cervix J Obstet Gynaecol India $66358-362$ https://doi.org/10.1007/s13224-015-0692-y PMID: 27486282 PMCID: 4958070

9. Shimizu I, Hayashi S, and Uehara M, et al (1983) Cutaneous metastases to the scalp from carcinoma of the uterine cervix Arch Dermatol 119 275-276 https://doi.org/10.1001/archderm.1983.01650280003001 PMID: 6838231 
10. Gairola M, Sharma D, and Mukhopadhyay P, et al (2000) Scalp metastasis of a uterine cervix carcinoma Obstet Gynecol Today $5488-489$

11. Chung J, Namiki T, and Johnson D (2007) Cervical cancer metastasis to the scalp presenting as alopecia neoplastica Int J Dermatol 46 188-189 https://doi.org/10.1111/j.1365-4632.2007.03183.x PMID: 17269974

12. Abhishek A, Ouseph $M$, and Sharma $P$, et al (2008) Bulky scalp metastasis and superior sagittal sinus thrombosis from a cervical adenocarcinoma: an unusual case J Med Imaging Radiat Oncol 52 91-94 https://doi.org/10.1111/j.1440-1673.2007.01918.x PMID: 18373834 